ИЗВЕСТИЯ АКАДЕМИИ НАУК ЭСТОНСКОИ ССР. ТОМ 30 Химия. 1981, № 1

\title{
СВЯЗЬ МЕЖДУ ИНДЕКСАМИ УДЕРЖИВАНИЯ И ФИЗИКО-ХИМИЧЕСКИМИ СВОЙСТВАМИ н-АЛКЕНОВ И $\boldsymbol{w}$-АЛКИНОВ
}

Kai KUNINGAS, Silvia RANG, O. EISEN. n-ALKEENIDE JA n-ALKOUNIDE RETENTSIOONIINDEKSITE JA FOUSIKALIS-KEEMILISTE OMADUSTE VAHELINE SEOS

Kai KUNINGAS, Silvia RANG, O. EISEN. THE RELATION BETWEEN RETENTION INDICES AND PHYSICO-CHEMICAL PROPERTIES OF $n$-ALKENES AND $n$-ALKYNES

Исследованием корреляций между индексами удерживания $I^{[1-3]}$ и некоторыми физико-химическими свойствами $н$-алкенов и $H$-алкинов $\mathrm{C}_{6}-\mathrm{C}_{14}$ (молекулярной рефракцией $R_{D}^{20}$, плотностью $d_{4}^{20}$, и показателями преломления $\left.n_{D}^{20}\left[{ }^{4-6}\right]\right)$, установлено, что величины $R_{D}^{20}$ и $I$ связаны между собой линейной зависимостью согласно уравнению

$$
I=a+b R_{D}^{20}
$$

где $a$ и $b-$ константы.

В таблице приведены рассчитанные методом наименьших квадратов на ӘВМ 1010В значения констант $a$ и $b$ для некоторых $\mu$-алкенов и $н$-алкинов на четырех различных жидких фазах.

В то же время не обнаружено линейной зависимости ни между величинами $I$ и $n_{D}^{20}$, ни между величинами $I$ и $d_{4}^{20}$.

В характере изменения индексов удерживания изученных соединений, с одной стороны, и их молекулярных рефракций, показателей преломления и плотностей, с другой, в зависимости от положения кратной связи в молекуле наблюдается аналогия (рисунок). Наивысшими значениями этих характеристик обладают 2-изомеры (исключая молекулярную рефракцию), наименьшими - 1-изомеры. Чем выше суммарная полярность молекул, тем выше указанные свойства. Из рисунка

Значения коэффициентов уравнения (1) для ряда углеводородов при $110^{\circ} \mathrm{C}$

\begin{tabular}{|c|c|c|c|c|c|c|c|c|}
\hline \multirow{2}{*}{$\begin{array}{c}\text { Угле- } \\
\text { водороды }\end{array}$} & \multicolumn{2}{|c|}{ Сквалан } & \multicolumn{2}{|c|}{ Апьезон $L$} & \multicolumn{2}{|c|}{$\begin{array}{l}\text { Полифениловый } \\
\text { эфир }\end{array}$} & \multicolumn{2}{|c|}{$\begin{array}{c}\text { Полиэтиленгли- } \\
\text { коль } 4000\end{array}$} \\
\hline & $a$ & $b$ & $a$ & $b$ & $a$ & $b$ & $a$ & $b$ \\
\hline 1-Алкены & $-55,73$ & 21,61 & $-48,40$ & 21,57 & $-14,61$ & 21,55 & 16,23 & 21,57 \\
\hline транс-2-Алкены & $-39,57$ & 21,49 & $-34,07$ & 21,46 & 39,86 & 21,43 & 29,14 & 21,50 \\
\hline цис-2-Алкены & $-33,20$ & 21,53 & $-28,62$ & 21,58 & 13,51 & 21,44 & 49,50 & 21,47 \\
\hline транс-3-Алкены & $-46,10$ & 21,35 & $-39,56$ & 21,24 & $-6,86$ & 21,32 & 25,11 & 21,14 \\
\hline цис-3-Алкены & $-37,57$ & 21,25 & $-31,30$ & 21,23 & 1,43 & 21,23 & 38,50 & 21,09 \\
\hline 1-Алкины & $-17,16$ & 21,62 & $-2,96$ & 21,56 & 104,60 & 21,56 & 216,62 & 21,97 \\
\hline 2-Алкины & 31,99 & 21,67 & 47,87 & 21,55 & 158,91 . & 21,71 & 253,82 & 21,69 \\
\hline 3-Алкины & 0,59 & 21,74 & 3,09 & 21,81 & 117,98 & 21,76 & 197,29 & 21,68 \\
\hline
\end{tabular}




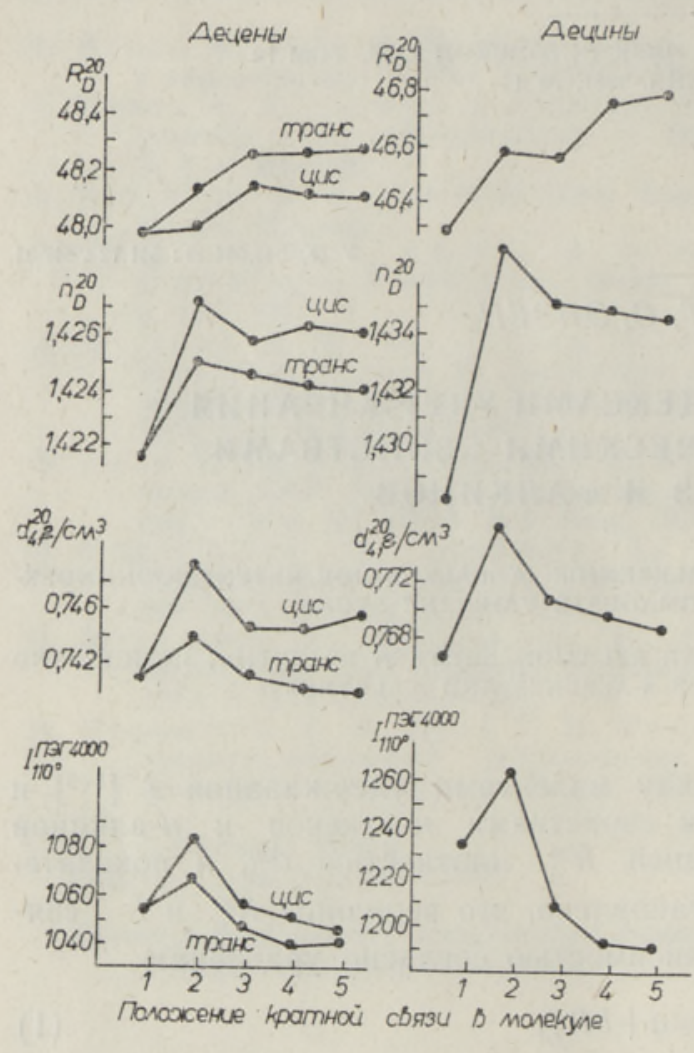

Зависимость значений молекулярной рефракции $R_{D}^{20}$, показателей преломления $n_{D}^{20}$, плотностей $d_{4}^{20}$ и индексов удерживания $I$ (полиэтиленгликоль 4000 - ПЭГ 4000) от положения кратной связи в молекуле.

видно, что у соединений изученных гомологических рядов значения $n_{D}^{20}$ и $d_{4}^{20}$, как и $I$, уменьшаются в порядке $\mu$-алкины > цис-алкены > транс-алкены.

Известно, что молекулярная рефракция является приближенной мерой оценки электронной поляризуемости молекул, которая, в свою очередь, характеризует роль дисперсионных сил при взаимодействии сорбата с сорбентом. Самое низкое значение $R_{D}^{20}$ характерно для 1-изомера данного $н$-алкена, несколько выше для цис-2-изомера. Среди н-алкенов с одинаковым положением двойной связи молекулярная рефракция у транс-изомера всегда выше, чем у циис-изомера. В группе изученных соединений наименьшими значениями $R_{D}^{20}$ обладают $H$-алкины. Значит, величины $R_{D}^{20}$, а следовательно, и поляризуемость уменьшаются в одном и том же порядке: транс-алкен > цис-алкен > $>$-алкин.

\section{Л И Т Е Р А Т Р А}

1. Rang, S., Kuningas, K., Orav, A., E isen, O. Capillary gas chromatography of $n$-alkynes, 1. Retention indices. - J. Chromatogr., 1976, v. 119, p. $451-460$.

2. Rang, S., Kuningas, K., Orav, A., Eisen, O. Capillary gas chromatography of $\mathrm{C}_{6}-\mathrm{C}_{14} n$-alkenes on polyphenylether and polyethylene glycol 4000. - Chromatographia, 1977, v. 10, N 2, p. 55-64.

3. Eise n. O., Orav, A., R a ng, S. Identification of normal alkenes, cyclopentenes and cyclohexenes by capillary gas chromatography. - Chromatographia, 1972 , v. 5 , N 11 , p. $229-239$.

4. Эльвельт А. Исследование физико-химических свойств изомеров положения связи и конфигурации нормальных алкенов. Канд. дис. Таллин, 1977.

5. Эльвельт А., Эй зен О. О физико-химических характеристиках изомерных н-децинов. - Изв. АН ЭССР. Хим., 1978, т. 27, № 1, с. $54-56$.

6. Э льв в льт А., О тс а Э., Э йзен О. Физико-химические характеристики изомерных $н$-октинов и $н$-нонинов. - Изв, АН ЭССР. Хим., 1979, т. 28, № 4, c. $287-289$. 